\title{
BAALC wt Allele
}

National Cancer Institute

\section{Source}

National Cancer Institute. BAALC wt Allele. NCI Thesaurus. Code C103992.

Human BAALC wild-type allele is located in the vicinity of $8 q 22.3$ and is approximately 90 $\mathrm{kb}$ in length. This allele, which encodes brain and acute leukemia cytoplasmic protein, may play a role in the functioning of neurons and hematopoietic cells. Aberrant expression may be associated with acute myeloid leukemia. 